Egyptian Journal of Aquatic Biology \& Fisheries

Zoology Department, Faculty of Science,

Ain Shams University, Cairo, Egypt.

ISSN $1110-6131$

Vol. 26(1): 99 - 124 (2022)

www.ejabf.journals.ekb.eg

\title{
Microbial Pigments: Sources and Applications in the Marine Environment
}

\author{
Sahar W. M. Hassan*, Mohamed A.A. Abdrabo and Asmaa elsayis ${ }^{3}$ \\ National Institute of Oceanography and Fisheres (NIOF), Egypt.
}

*Corresponding author: saharwefky@yahoo.com

ARTICLE INFO

Article History:

Received: Nov. 1, 2021

Accepted: Dec. 3, 2021

Online: Jan. 12, 2022

Keywords:

Microbial pigments, marine sources,

applications
ABSTRACT

Pigments are colored metabolites secreted by different microorganisms. The uses of microbial pigments have amplified many folds due to numerous benefits over the synthetic pigments and are generally preferred due to the simplicity of culturing and extraction of pigments, cost-effective, safety for humans, thus having a wide range of applications in pharmaceutical, textile, cosmetics and food industries. Marine species represent a noteworthy sector of the oceanic population, which significantly produces biologically active moieties with different industrial and medical applications. Owing to the remarkable importance of microbial pigments in the marine ecosystem, the current review sheds light on marine microbial sources of pigments together with some applications in the marine environment. It also encompasses the need for prolonging the survey on novel extreme habitats and highlighting the future potential, targeting to contribute to the global economy.

\section{INTRODUCTION}

\section{Introduction}

Pigments are crucial compounds for several industries and can be used as color intensifiers, antioxidants, additives, etc. Pigments come in a wide diversity of colors; some of them are water soluble. Traditional sources of colorants including natural products such as anthraquinones and flavonoids are produced by animals and plants. For example, a deep red anthraquinone and carminic acid produced by insects are now used as a pigment in food colors, crimson ink, paints and cosmetics. Although synthetic colors are well-designed and are mostly used in the world marketplaces (42\%) (Okafor $\boldsymbol{e t}$ al., 2016; Rajapaksha et al., 2017), they have various side effects (e.g., teratogenic, cancer, etc.) (Okafor $\boldsymbol{e t}$ al., 2016). In addition, some of them are non-biodegradable such as textile dyes, producing problems to humans and aquatic organisms (Saini, 2017; Berradi et al., 2019; Lellis et al., 2019). 
Now a world trend targeting the usage of biodegradable and eco-friendly natural colorants is increasing day by day. Therefore, investigators are trying to discover alternative biological, physical, and chemical techniques instead of the synthetic colors to evade the harmful effects on the environmental and public health (Roy, 2018; Jamee et al., 2019).

Accordingly, microbial pigments have attracted an excessive request to improve textile grade, natural pigments, food grade and drug grade. The high request of natural microbial pigments are due to the talented limitless properties, including high manufacture of required pigments quantity, being eco-friendly, having no side effects, biodegradability, easiness of cultivation, less cost-effectiveness, stability, adaptability to various environments, optimization, genetic engineering. Further pigment properties worth mentioning, including their essential applications in several features, such as biomedical evolutionary, ecological, industrial and agriculture investigations (Dufossé, 2020; Venil et al., 2020).

Several microorganisms are well-known to produce a an extensive diversity of pigments with inestimable industrial and biological activities (Ramesh et al., 2019; Nawaz et al., 2021). Absence of information on isolation sources of microbial pigments and their bioprospecting methods would make investigators make trials in research of natural microbial pigments. Constructed on the available review of the literature (Ramesh et al., 2019; Venil et al., 2020), current investigators are searching for novel strains, producing pigments such as chlorophylls, phycoerythrin and phycobiliproteins (Joye \& Kostka, 2020; Sigwart et al., 2021).

Spectral pigments have been determined from microbial and higher sources for different uses. However, the ecological significance and the biotechnological applications of nonspectral pigments in nature are not well investigated. Thus, investigations on these pigments require further research (Chatragadda \& Dufossé, 2021).

The reserve of pigments, rate of production, price, effectiveness, durability, transport, sustainability, palatability, regulatory, jurisdictive, consumers' demand, and approval are the chief basics required for applications in marketable applications (Ramesh et al., 2019).

\section{Microbial pigments}

Microbial pigments exert numerous roles in the survival and construction of the ecosystem. Significantly, pigments produced by fungi, bacteria, microalgae, and yeast compromise an extensive assembly of dyes, colorants and food applications. The demand for natural pigments is more than synthetic pigments due to the side effects of synthetic pigments on human healthiness. Consequently, further research regarding microbial 
pigments is required to find prospective industrial applications (Chatragadda \& Dufossé, 2021). Fig. (1) represents different types of microbial pigments.

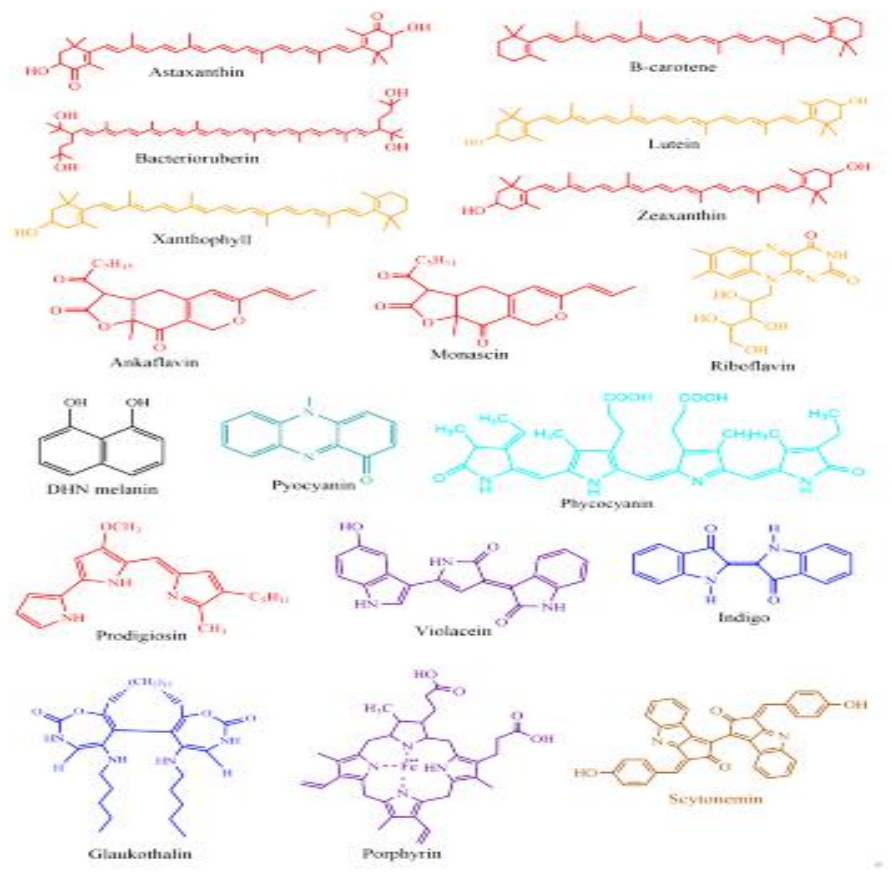

Fig. 1. Chemical structures of microbial pigments (Chatragadda \& Dufossé, 2021)

\section{Habitats and ecology of microorganisms producing pigments}

A superfluity of research has described the isolation microorganisms producing pigments such as fungi, yeast and bacteria from terrestrial and marine environments. They are spread in several ecological area, from tropical to Polar Regions and from deepsea to aerial districts. Microbes from divergent ecological areas are assumed to endure extreme conditions by the production of pigments. Some pigment producers, such as yeast, bacteria, and fungi that exist in terrestrial areas go into shore areas through the disposal of domestic sewages and hospitals, thus acclimatizing to coastal environment (Ramesh et al., 2019).

Studies indicate that bacteria producing pigments could be classified into two groups; namely, true marine producers from mostly marine derivation and adaptive producers devised from terrestrial origin, which can live and multiply in aquatic ecosystem (Fig. 2). Regardless of the mutual existence in terrestrial area, marine producers gained more consideration owing to the diverse pigments production. Marine microbial pigments are considered as novel chromogenic compounds for industrial and biotechnological applications. The incidence of pigmented microbes in aquatic environment differ in terms of nutritional and geographical circumstances. For instance, 
the diversity of pigmented heterotrophic bacteria is fewer in abundance comparing to the vast variety of heterotrophic bacteria in the marine area. The distribution and abundance may diverge reliant on seasonal deviation, accessibility of nutrients and sampling sites. High occurrence of bacteria producing pigments is noticed in ice cores (Zhang et al., 2008), glaciers (Miteva et al., 2004), salt lakes (Khanafari et al., 2009), air-water interfaces (Hermansson et al., 1987), underlying waters (Agogué et al., 2005) (sea surface microlayer), deep sea hydrothermal vents (Yurkov et al., 1999), and hot springs (e.g., Thermus). Moreover, different pigmented populations have been gained from lava caves (Hathaway et al., 2014).

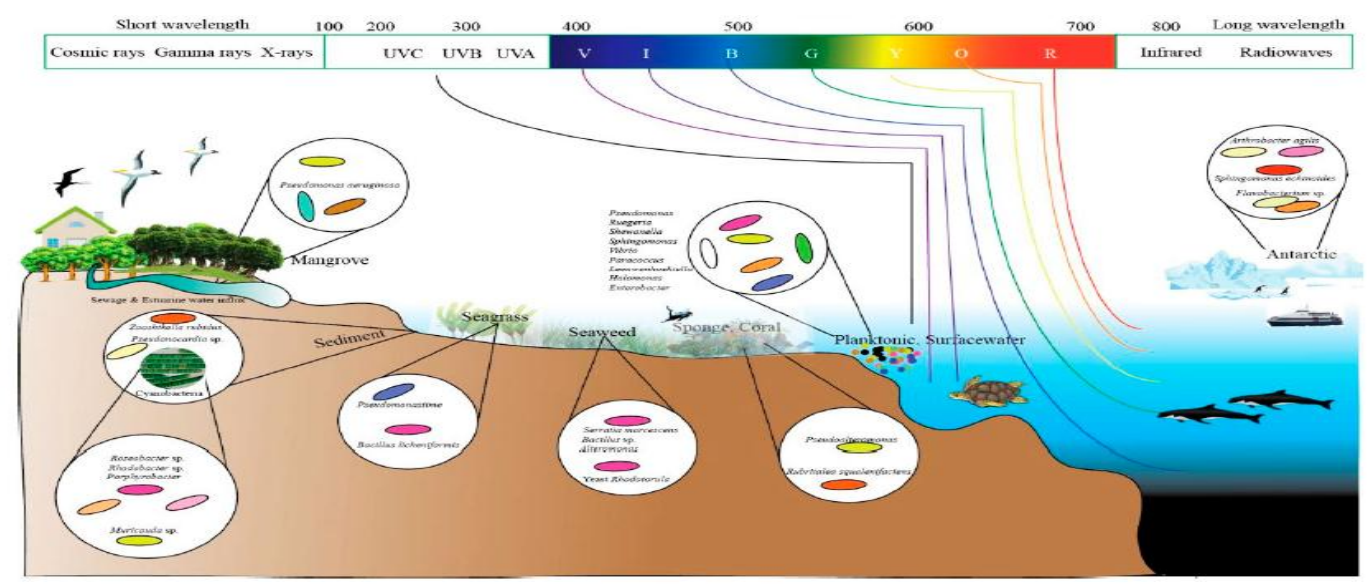

Fig. 2. Distribution of marine pigment producing microorganisms in different places

(Ramesh et al., 2019)

\section{Microbial sources of pigments}

Different research studies have been conducted to substitute synthetic pigments with natural pigments due to the richness of nature with pigment producing organisms. In 2011 , total sales of natural colors amounted to a rate of $\$ 600$ millions. Microorganisms are acknowledged as a prospective source for production of biopigment due to their advantages over plants regarding cost efficiency, stability, availability, yield, labor and easiness in processing (Joshi et al. 2003). Varieties of bio-pigments, such as melanins, violancein, carotenoids, monascins, flavins and quinines are produced by microorganisms (Duffose, 2006).

Microbial cultivation can be achieved through submerged and solid fermentation, depending on industrial organic waste/ natural raw material. The majority of the microbial pigments possess not only the function as coloring agents in various cosmetics and food processing, but also antimicrobial, anti-inflammatory, anticancer and antioxidant applications (Venil \& Lakshmanaperumalsamy, 2009). Moreover, there is a vast use for coloring agents in textile, paper and printing, plastic and paint industries. 
The low microbial proportion that can be cultured and grow under laboratory conditions is one of the obstacles for the characterization of microbial pigments. In fact, more than $99 \%$ of marine microbes have not been effectively cultured under lab conditions (Jiao et al., 2021). Almost 107 kinds of bacteria were gained from 1 gram of sediment, among which only $5 \%$ of the microorganisms were capable to grow in the lab (Sun et al., 2019).

This phenomenon is determied as the "great plate count anomaly" (Staley \& Konopka, 1985), which defines the differences between the cell number from the normal environment forming colonies on agar plates and that is countable using microscopes. Appropriately, in marine ecosystems, only 0.01 to $0.1 \%$ of marine bacterial cells yield colonies using standard plating techniques (Connon \& Giovannoni, 2002). The second challenge is realizing an acceptable amount of the favorite metabolites to permit identification of bacterial pigments and their bioactivity (Joint et al., 2010). Another challenge in this investigation relates to genome mining. As the number of the available genomes is increasing, genome mining is a suitable challenging way to identify new natural products and to confirm data (Albarano et al., 2020).

\subsection{Bacteria}

The most extracted pigments from marine bacterial isolates in the past 5 years are shown in Table (1). At least seventeen kinds have been effectively isolated from their natural habitats, including sediments and seawater in association with marine invertebrates. It has been widely reviewed that marine sediment contains unexploited prospective for novel bacteria producing bioactive metabolites compared to seawater (Bech et al., 2020). It was reported that sediments and seawater comprise a similar number of distinct bacterial species with a mean \pm standard deviation (SD) of $1452 \pm 74$ species for sediments and 1378 \pm 61 species for seawater (Bech et al., 2020). Symbiosis between microorganisms and invertebrates as hosts is mutual in marine environments and relies on chemical defense. It is a proficient policy for survival (Flórez et al., 2015) leading to production of variability of biochemical traits due to coevolution with their specific hosts, making them a rich source of metabolites, particularly pigments with commercial interesting bioactivities (Zhang et al., 2015; Blockley et al., 2017; Torregrosa-crespo et al., 2018).

Carotenoids "as a group of the new compounds that have been categorized over the past 5 years" are yellow to orange-red pigments, generally containing a 40-carbon skeleton composed of 8-isoprene units. Seven uncommon compounds include C50 and C45 carotenoids. By 2017, more than 250 carotenoids of marine source were recognized (Galasso et al., 2017), and the inimitable compositions existing in marine microorganisms have encouraged the usage of carotenoids as a chemical mark for quick chemotaxonomic profiling. 
Table 1. Recent bio-pigments extracted from marine bacterial isolates determined in the last five years (Brotosudarmo et al., 2020)

\begin{tabular}{|c|c|c|c|c|c|}
\hline Pigment & $\begin{array}{l}\text { Chemical } \\
\text { Formula }\end{array}$ & $\begin{array}{c}\Lambda_{\max } \\
(\mathbf{n m})\end{array}$ & $\begin{array}{l}\text { Molecular } \\
\text { ion }(m / z)\end{array}$ & $\begin{array}{c}\text { Marine bacterial } \\
\text { species }\end{array}$ & $\begin{array}{l}\text { Therapeutic } \\
\text { application }\end{array}$ \\
\hline $\begin{array}{l}\text { Carotenoid group } \\
\text { Decaprenoxanthin }\end{array}$ & $\mathrm{C}_{50} \mathrm{H}_{72} \mathrm{O}_{2}$ & $417,442,471$ & $\begin{array}{c}705.6 \\
{[\mathrm{M}+\mathrm{H}]+}\end{array}$ & $\begin{array}{c}\text { Arthrobacter sp. } \\
\text { P40 }\end{array}$ & Antioxidant \\
\hline $\begin{array}{l}\text { Decaprenoxanthin } \\
\text { monoglucoside }\end{array}$ & $\mathrm{C}_{56} \mathrm{H}_{82} \mathrm{O}_{7}$ & $417,442,471$ & $\begin{array}{c}867.6 \\
{[\mathrm{M}+\mathrm{H}]+}\end{array}$ & $\begin{array}{c}\text { Arthrobacter sp. } \\
\text { P40 }\end{array}$ & Antioxidant \\
\hline $\begin{array}{l}\text { Decaprenoxanthin } \\
\text { diglucoside }\end{array}$ & $\mathrm{C}_{62} \mathrm{H}_{92} \mathrm{O}_{12}$ & $417,442,471$ & $\begin{array}{c}1029.6 \\
{[\mathrm{M}+\mathrm{H}]+}\end{array}$ & $\begin{array}{c}\text { Arthrobacter } \mathrm{sp} . \\
\text { P40 }\end{array}$ & Antioxidant \\
\hline $\begin{array}{l}2^{0} \text {-Hydroxy- } \\
\text { astaxanthin }\end{array}$ & $\mathrm{C}_{40} \mathrm{H}_{52} \mathrm{O}_{5}$ & 478 & $613[\mathrm{M}+\mathrm{H}]+$ & $\begin{array}{l}\text { Brevundimonas sp. } \\
\text { strain N-5 }\end{array}$ & Antioxidant \\
\hline $\begin{array}{l}2,2^{0} \text {-Dihydroxy- } \\
\text { astaxanthin }\end{array}$ & $\mathrm{C}_{40} \mathrm{H}_{52} \mathrm{O}_{6}$ & 478 & $\begin{array}{c}629.0 \\
{[\mathrm{M}+\mathrm{H}]+}\end{array}$ & $\begin{array}{l}\text { Brevundimonas } \\
\text { scallop } \\
\text { Brevundimonas sp. } \\
\text { strain N-5 }\end{array}$ & Antioxidant \\
\hline Dehydroflexixanthin & $\mathrm{C}_{40} \mathrm{H}_{52} \mathrm{O}_{3}$ & - & $581[\mathrm{M}+\mathrm{H}]+$ & $\begin{array}{l}\text { Rhodopirellula } \\
\text { rubra LF2T }\end{array}$ & Antioxidant \\
\hline $\begin{array}{c}2^{0} \text {-Isopentenyldehy- } \\
\text { drosaproxanthin }\end{array}$ & $\mathrm{C}_{45} \mathrm{H}_{64} \mathrm{O}_{2}$ & 470,500 & $637[\mathrm{M}+\mathrm{H}]+$ & $\begin{array}{l}\text { Rhodopirellula } \\
\text { rubra } \text { LF2T }\end{array}$ & Antioxidant \\
\hline Saproxanthin & $\mathrm{C}_{40} \mathrm{H}_{56} \mathrm{O}_{2}$ & $444,470,5$ & $590[\mathrm{M}+\mathrm{Na}]+$ & $\begin{array}{l}\text { Rhodopirellula } \\
\text { rubra } \text { LF2T } \\
\text { Rubinisphaera } \\
\text { brasiliensis } \text { Gr7 }\end{array}$ & Antioxidant \\
\hline Zeaxanthin-sulfate & $\begin{array}{c}\mathrm{C}_{40} \mathrm{H}_{55} \mathrm{SO}_{5} \\
\mathrm{Na} \\
\end{array}$ & $427,453,481$ & $\begin{array}{c}648.5 \\
{[\mathrm{M} \text { ? } \mathrm{Na}] \text { ? }}\end{array}$ & $\begin{array}{l}\text { Erythrobacter } \\
\text { flavus } \mathrm{KJ} 5\end{array}$ & Antioxidant \\
\hline $\begin{array}{l}\text { Quinone group } \\
\text { Bisantraquinone } 1\end{array}$ & $\mathrm{C}_{32} \mathrm{H}_{25} \mathrm{O}_{9}$ & $\begin{array}{l}229,261,287 \\
361,415\end{array}$ & $\begin{array}{c}553.15 \\
{[\mathrm{M}+\mathrm{H}]+}\end{array}$ & $\begin{array}{c}\text { Ecteinascidia } \\
\text { turbinada }\end{array}$ & $\begin{array}{l}\text { Antibacterial } \\
\text { Anticancer }\end{array}$ \\
\hline Fridamycins $\mathrm{H}$ & $\mathrm{C}_{25} \mathrm{H}_{26} \mathrm{O}_{11}$ & $231,253,293$ & $\begin{array}{c}503.15 \\
{[\mathrm{M}+\mathrm{H}]+}\end{array}$ & $\begin{array}{l}\text { Actinokineospora } \\
\text { spheciospongiae }\end{array}$ & $\begin{array}{c}\text { Antitrypanoso } \\
\text { mal }\end{array}$ \\
\hline Fridamycins I & $\begin{array}{c}\mathrm{C}_{32} \mathrm{H}_{33} \mathrm{NO}_{10} \\
\mathrm{Na}\end{array}$ & $232,253,294$ & $614[\mathrm{M}+\mathrm{H}]+$ & $\begin{array}{c}\text { sp. nov. } \\
\text { Actinokineospora } \\
\text { spheciospongiae }\end{array}$ & $\begin{array}{c}\text { Antitrypanoso } \\
\text { mal }\end{array}$ \\
\hline $\begin{array}{l}\mathrm{N} \text {-acetyl-N demethyl- } \\
\text { mayamycin }\end{array}$ & $\mathrm{C}_{27} \mathrm{H}_{25} \mathrm{NO}_{8}$ & 328,443 & $\begin{array}{c}514.15 \\
{[\mathrm{M}+\mathrm{Na}]}\end{array}$ & $\begin{array}{l}\text { sp. nov. } \\
\text { Streptomyces sp. } \\
\text { 182SMLY }\end{array}$ & Antibacterial \\
\hline Mersaquinone & $\mathrm{C}_{19} \mathrm{H}_{12} \mathrm{O}_{6}$ & $\begin{array}{c}218,277,308 \\
350,480,515 \\
550\end{array}$ & $\begin{array}{c}337.07 \\
{[\mathrm{M}+\mathrm{H}]+}\end{array}$ & Streptomyces sp. & Antibacterial \\
\hline $\begin{array}{c}\text { Streptoanthra quinone } \\
\text { A }\end{array}$ & $\mathrm{C}_{28} \mathrm{H}_{22} \mathrm{O}_{8}$ & $220,330,445$ & $\begin{array}{c}509.12 \\
{[\mathrm{M}+\mathrm{Na}]+}\end{array}$ & $\begin{array}{c}\text { Streptomyces sp. } \\
\text { 182SMLY }\end{array}$ & Antibacterial \\
\hline $\begin{array}{l}\text { Prodigiosin group } \\
\text { Prodigiosin }\end{array}$ & $\mathrm{C}_{20} \mathrm{H}_{25} \mathrm{~N}_{3} \mathrm{O}$ & 537 & $\begin{array}{c}324.4 \\
{[\mathrm{M}+\mathrm{H}]+}\end{array}$ & $\begin{array}{c}\text { Pseudomonas rubra } \\
\text { strain PS1 } \\
\text { and SB14 } \\
\text { Zooshikella } \mathrm{sp} . \\
\text { Streptomyces } \mathrm{sp} .\end{array}$ & $\begin{array}{c}\text { Antibacterial } \\
\text { Anticancer } \\
\text { Antiinflammat } \\
\text { ory }\end{array}$ \\
\hline $\begin{array}{c}\text { Phenazine group } \\
\text { Phenazine-1- } \\
\text { carboxylic acid }\end{array}$ & $\mathrm{C}_{13} \mathrm{H}_{8} \mathrm{~N}_{2} \mathrm{O}_{2}$ & $252,365,354$ & $\begin{array}{c}247.05 \\
{[\mathrm{M}+\mathrm{Na}]+}\end{array}$ & $\begin{array}{l}\text { Pseudomonas } \\
\text { aeruginosa } \\
\text { strain PA31x }\end{array}$ & $\begin{array}{l}\text { Antibacterial } \\
\text { Antifungal }\end{array}$ \\
\hline Pyocyanin & $\mathrm{C}_{13} \mathrm{H}_{11} \mathrm{~N}_{2} \mathrm{O}$ & $\begin{array}{c}201,238,318 \\
710,886 \\
\end{array}$ & $211[\mathrm{M}]+$ & $\begin{array}{c}\text { Pseudomonas } \\
\text { aeruginosa }\end{array}$ & Antibacterial \\
\hline $\begin{array}{c}\text { Violacein group } \\
\text { Violacein }\end{array}$ & $\mathrm{C}_{20} \mathrm{H}_{13} \mathrm{~N}_{3} \mathrm{O}_{3}$ & 585 & $\begin{array}{c}344.12 \\
{[\mathrm{M}+\mathrm{H}]+}\end{array}$ & $\begin{array}{c}\text { Janthinobacterium } \\
\text { lividum } \\
\text { Chromobacterium } \\
\text { violaceum } \\
\text { Pseudoalteromonas } \\
\text { byunsanens }\end{array}$ & $\begin{array}{l}\text { Antimicrobial } \\
\text { Anticancer }\end{array}$ \\
\hline
\end{tabular}


Newly recognized marine bacteria that yield high levels of astaxanthin and its derivatives, such as 20-hydroxyastaxanthin and 2,20-dihydroxyastaxanthin, have also been studied (Asker, 2017; Liu et al., 2020). The distinctive structure of astaxanthin, which contains both hydroxyls and a keto group, shows a vital role in neutralizing reactive oxygen species (ROS) (Brotosudarmo et al., 2020). Newly described bioactive pigments from the quinone group have also been described, such as fridamycins, fridamycins $\mathrm{H}$ and I from Actinokineospora spheciospongiae sp. nov., beside 3 known pigments (actinosporins C, D and G) (Tawfike et al., 2019).

Mersaquinone, a new tetracene derivative known for its antibacterial activity towards methicillin-resistant Staphylococcus aureus, was positively reported and characterized (Kim et al., 2020). In addition, 2 new polycyclic anthraquinones, streptoanthraquinone A and $\mathrm{N}$-acetyl-N-demethyl-mayamycin, existing in Streptomyces sp. 182SMLY were gained from a sediment sample at a $3.6 \mathrm{~m}$ depth (Liang et al., 2016). Although prodiginines were originally recognized from the terrestrial bacterium Serrantia marcescens, these pigments were later gained from a number of bacteria in diverse marine habitats, for example Pseudomonas rubra strains PS1 and SB14, which were isolated from seawater (Setiyono et al., 2020). Furthermore, they were gained from Zooshikella sp. and Streptomyces sp. in sediment (Ramesh et al., 2020). Phenazine pigments, including pyocyanin and phenazine-1-carboxylic acid were successfully characterized from Pseudomonas aeruginosa isolated from sediment (Zhang et al., 2017; DeBritto et al., 2020). Fig. (3) represents different classes of pigments produced by marine bacteria. The search for novel pigments produced by marine bacteria during 19752021 is illustrated in Fig. (4). 


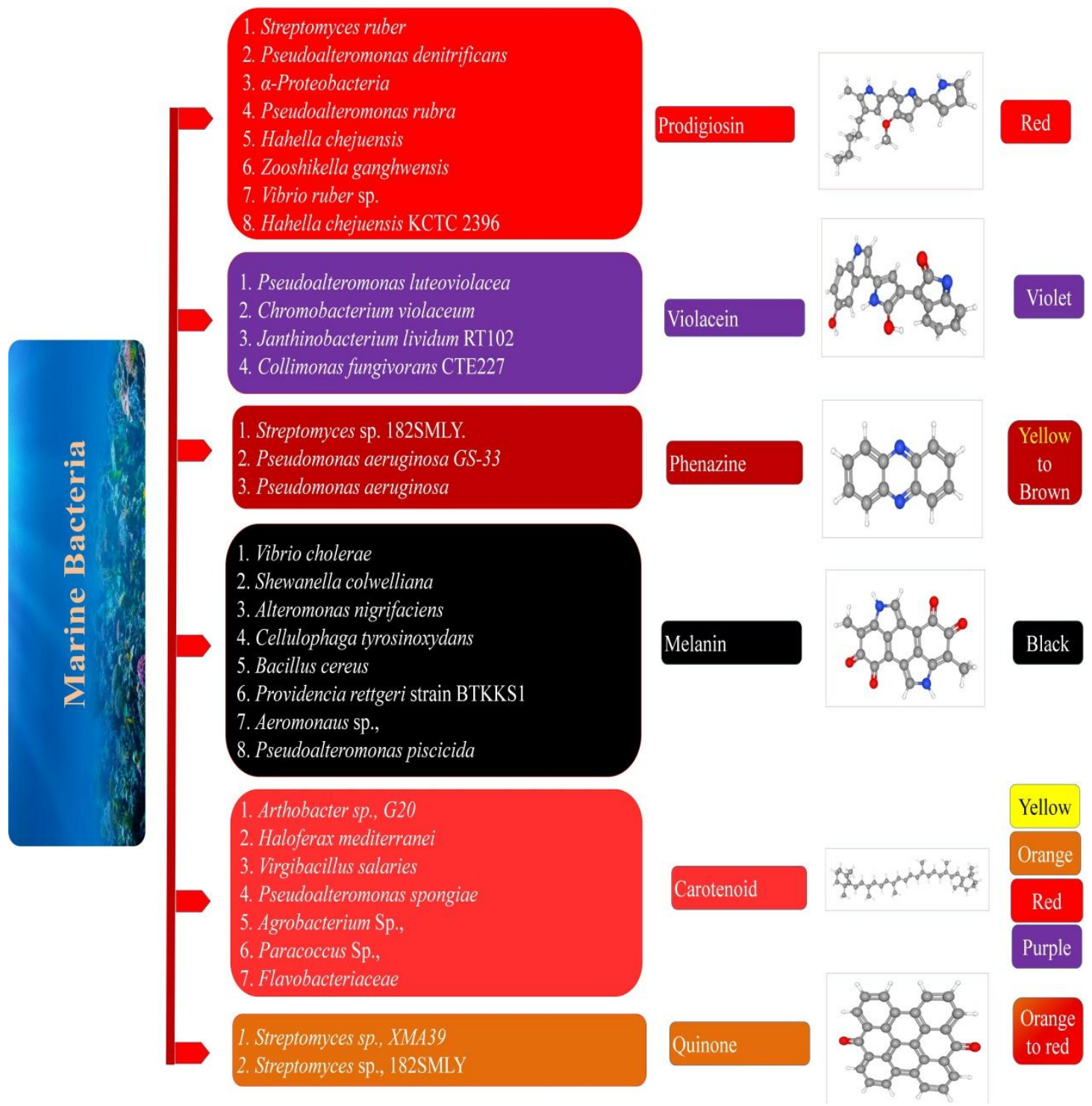

Fig.3. Kinds of marine bacterial pigments (Velmurugan et al., 2020) 


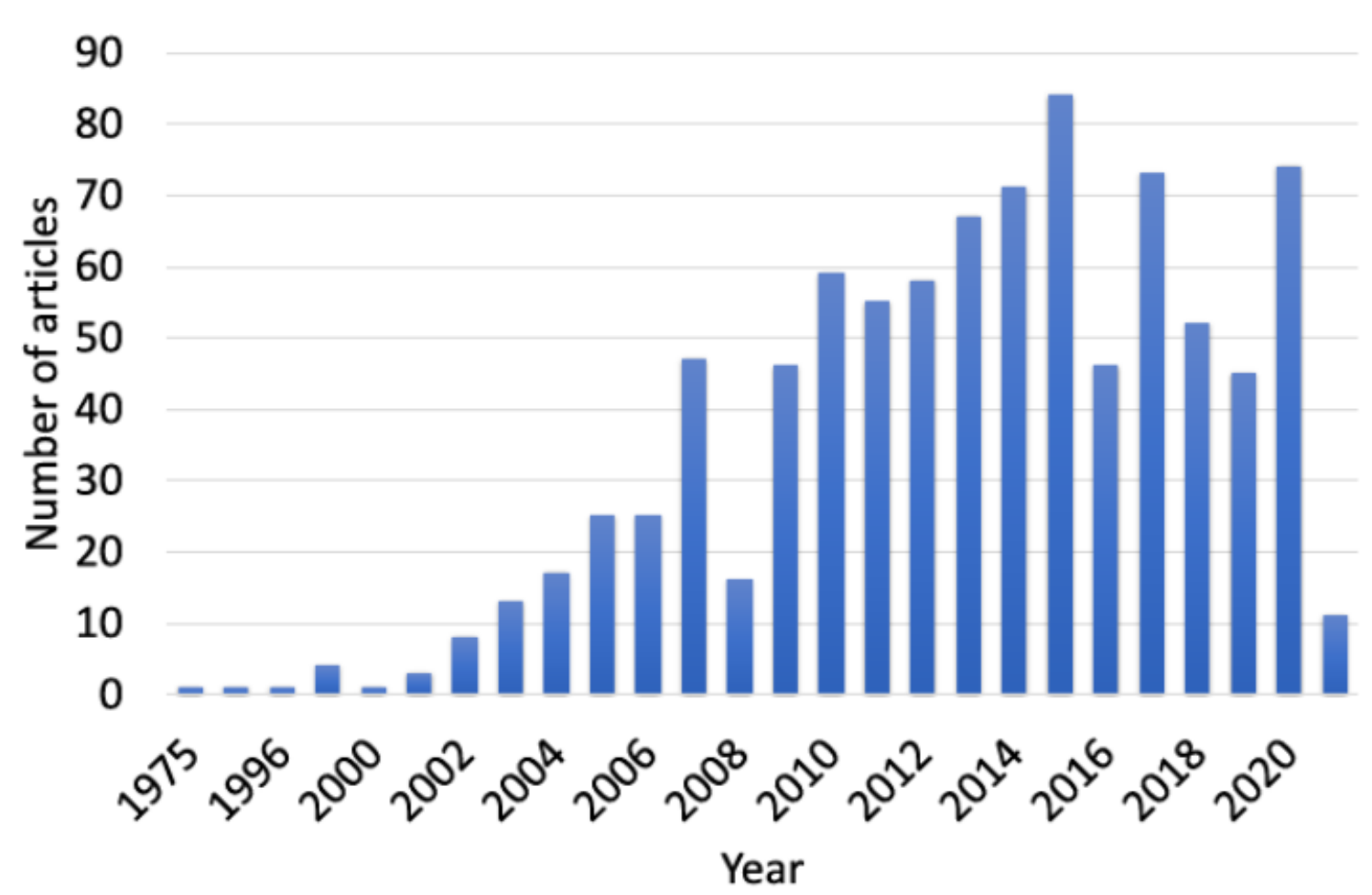

Fig. 4. Novel bacterial pigments produced from 1975 to 2021 (Velmurugan et al., 2020).

\subsection{Actinobacteria}

Actinobacteria is the energetic genera in the excretion of secondary metabolites with unique compounds that can exhibit effectively vital traits in industrial applications. Sometimes production of pigments by actinobacteria has an imperative role in characterizing them. They are extensively used as coloring agents in printing industry, dying industry, textile industry and food industry (Chakraborty et al., 2015).

Melanins represent the most mutual pigmented compounds produced by actinobacteria with colors ranging from black, brown to olive. In addition, they are produced by carotenoids with colors ranging from red, yellow, and pink to violet and from actinorhodin-related blue pigments (Rao et al., 2017). Carotenoids group exhibits antioxidant capabilities and is used as a natural colorant in food, cosmetics, textile industries and pharmaceutical products (Parmar \& Singh, 2018).

However, extraction of pigment from actinobacteria is not much experienced due to the limited fermentation methods. In some cases, the capability of the microorganism to yield pigment is either extremely improved or completely degraded due to the culturing techniques, the improper nutrition or other unknown explanations. Therefore, it 
may be expected that incidence of strains which produces pigments with stability deserves study (Chakraborty et al., 2015).

\subsection{Fungi}

Marine derived fungi have high diversity, and they exist in different habitats (Fig. 5). Their unique production of secondary components helps them survive in extreme environmental conditions, such as high pressure, high or low temperature, salinity and absence of light. These conditions lead to create progressive extremophiles capable of yielding certain exclusive compounds (Coker, 2016; Duarte et al., 2019). Fungal strains from marine location exemplify a key basis of novel pigments and could be objective zones for marketable research.

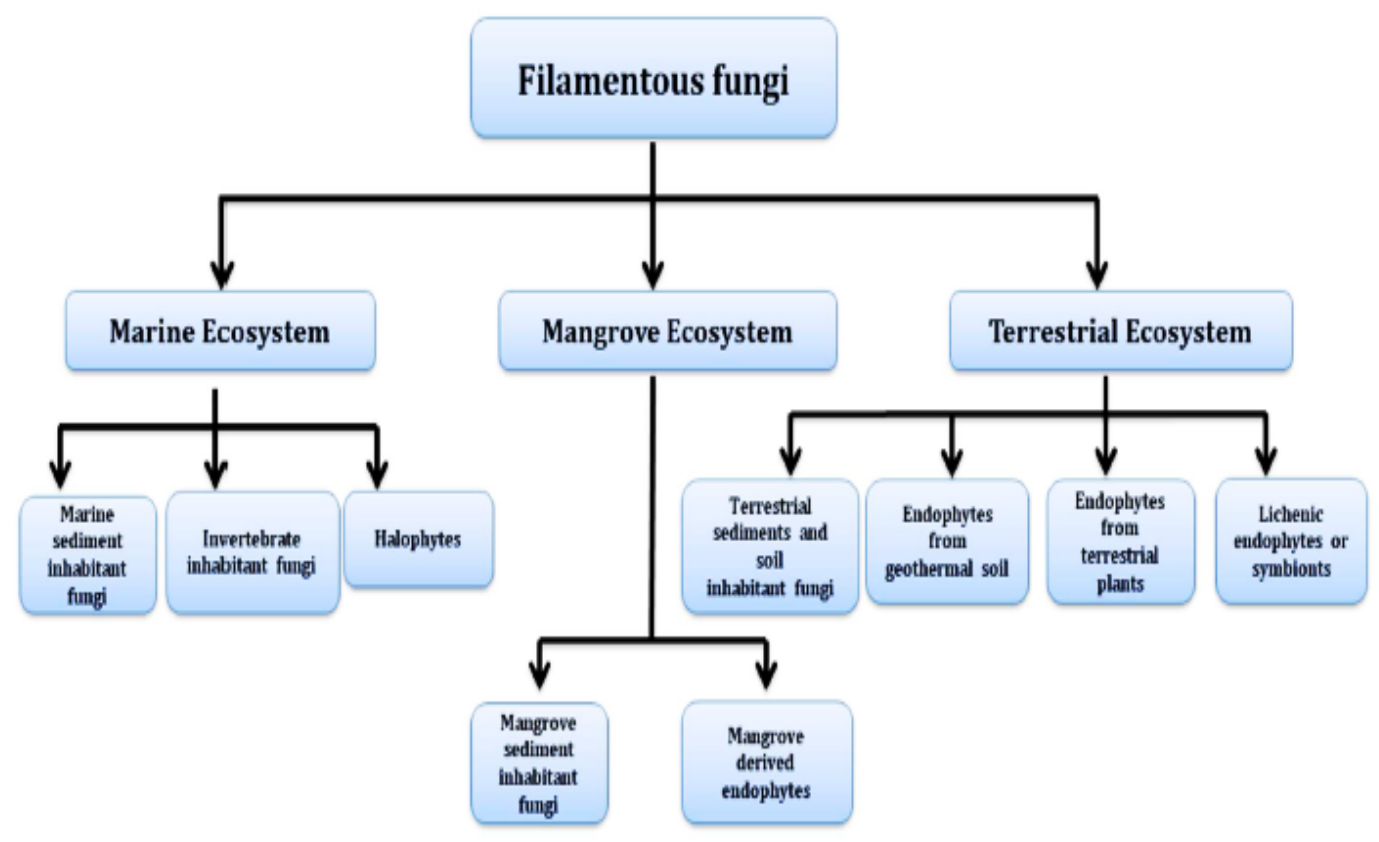

Fig.5. Several ecosystems forming a source of pigmented fungi (Kalra et al., 2020)

Mycologists have been interested in fungal pigments production since the $19^{\text {th }}$ century regarding them as a reservoir for the manufacture of food grade pigments. Fungal species yield a varied group of pigments from numerous groups such as anthraquinones, melanins, azaphilones, hydroxyanthraquinones, oxopolyene, carotenoids, naphthoquinone and quinones (Fig. 6) (Xie et al., 2016; Chuyen \& Eun, 2017; Pombeiro-Sponchiado et al., 2017). 


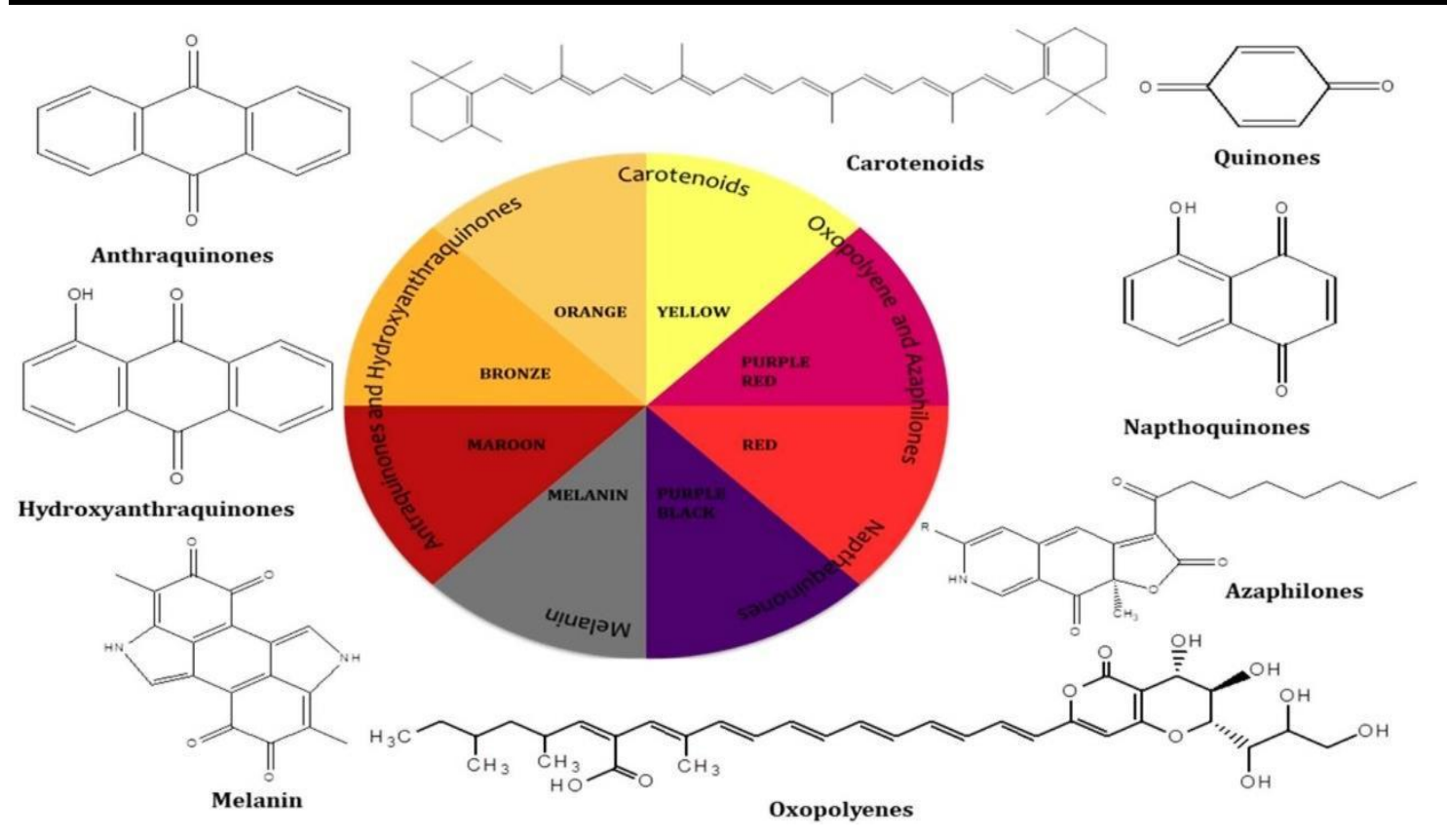

Fig. 6. Different kinds of colors representing different kinds of compounds (Kalra et al., 2020)

The first natural red pigment Arpink redTM pigment (Natural redTM) was produced from the soil fungus Penicillium oxalicum var. armeniaca CCM 8242 (Caro et al., 2017). Several produced pigments are derivatives of polypeptides produced mainly by Monascus spp and Neurospora spp. and are classified as the ascomycetous fungi. Terpenoids, polyphenols, and carotenoids are other groups of polyketide based structure.

Several types of the produced natural pigments have a series of pharmacological applications, and they aid fungi in several biological actions, as for instance carotenoids (Gmoser et al., 2017). They prevent the harmful effects of photooxidation and melanins and protect against environmental stress (Dufosse et al., 2014), in addition to flavins which help as enzyme cofactors (Rao et al., 2017). Although pigments produced by fungi have gained diverse biological activities, the factors that regulate the production and physiological roles are mostly unstudied (Sen et al., 2019).

\section{i. Invertebrate inhabitant fungi}

Sessile and non-sessile invertebrates including squirts, sponges, and corals that are found in the aquatic ecosystem with brilliant colors, resulting from symbiotic microorganism and photosynthetic pigments found inside the invertibtates. Xu et al. (2008) examined fungi from tropical coral reefs to assess the degree of their bioactive metabolites. The previous authors isolated two novel yellow pigments from the Aspergillus sp. in the coral reef of Manado, Indonesia (Xu et al., 2008). Additionally, Eurotium cristatum (ECE) isolated from the marine sponge Mycale sp. secreted a yellow 
colored pigment known as 2-(2', 3-epoxy-1',3'-heptadienyl)-6-hydroxy- 5-(3-methyl-2butenyl) benzaldehyde and 1,8-dihydroxy-6-methoxy-3-methyl-9,10-anthracenedione (physcion) (Almeida et al., 2010).

In another research, an array of orange/red pigments was produced by Talaromyces albobiverticillius (B and C) (Venkatachalam et al., 2019). These species belong mostly to the Talaromyces, Penicillium and Aspergillus, genera (Fouillaud et al., 2017). They are important genera for industry. Moreover, Alternaria is recognized for the bioactive compounds such as anthraquinone derivatives, which represent commonly pigmented molecules with extensive array of bioactivities. Zheng $\boldsymbol{e t}$ al. (2012) isolated several anthraquinone and hydroanthraquinones from the fungal isolate Alternaria sp. ZJ2008003 existing in soft coral of South China Sea. Some of the isolated molecules, with yellow, red, and pink colors, form an additional indication of the wide range of colors attainable from invertebrates.

\section{ii. Halophytes}

Halophilic extremophiles are microbes that can grow and survive in regions of high salt $(\mathrm{NaCl})$ content. They have excessive implication in biotechnological uses because of their capability to produce plentiful quantities of extracellular compounds (Ali et al., 2014) from which melanins represent a group of these pigmented compounds, making a vital point in several cosmetic and pharmaceutical uses. The halophilic Phaeotheca triangularis and Trimmatostroma salinum gained from the halophiles area of Adriatic Sea was detected as a melanin producer (Kogej et al., 2004). On the other hand, black yeast Hortaea wernecki forms a diffusible dark pigment on top of the growing potato dextrose agar. The produced pigment has an excessive important activity against Vibrio parahaemolyticus and Salmonella typhi (Rani et al., 2013).

Halotorelant fungal species comprise some quinone compounds with bright colors, among which Variecolorquinones A and B were recorded being secreted by Aspergillus variecolor B-17 (Wang et al., 2007). Production of colors in the blue range made halophytes exhibit promising importance to food industry.

\section{iii. Mangrove ecosystem}

Mangrove ecosystems provide an extraordinary diverse environment, offering distinctive things of both terrestrial and marine ecosystems in one ecosystem. However, tidal habitat, high temperature, extreme stress and the fluctuating saline, surroundings of the mangrove validate a restricted number of kinds to survive in such intimidating environment (Kathiresan \& Bingham, 2001). Consequently, the species inhabiting this environment represent an extremely rich area for substantial active and novel metabolites. 
Nevertheless, limited studies have addressed mangrove fungi despite of their prospective secretion of a range of pigments (Zhang et al., 2012).

\section{iv. Lichens and endolichenic fungi}

Lichens have significant rank and have become the emphasis of substantial medicinal concerns because of the incidence of distinctive compounds (Calcott $\boldsymbol{e t}$ al., 2018). Lichens represent a group of microorganisms with a close symbiotic association between the algal partner and fungal partner (DePriest, 2004). In this relationship, the fungal partner shields the algal partner from antagonistic geoclimatic effects. The production of pigmented molecules is a way of fungal partner to protect algal partner from ultraviolet radiation (Nguyen et al., 2013). Although the slow rate of lichen growth in nature is a main obstacle to gain the produced pigments for commercial manipulation, modern studies have designated gaining pigments from cultivated fungi which opened novel trails for marketing commercial usages of pigments from lichens (Calcott $\boldsymbol{e t}$ al., 2018). Miyagawa et al. (1994) extracted two novel pigments, known as graphenone and graphisquinone, from the fungi of Graphis scripta and Graphis desquamescens. Some types of mycobionts have been detected in lichen forming new compounds under extreme circumstances such as osmotic hassle in the lab, which are not formed in the normal conditions (Kalra et al., 2020).

A pigment includes a yellow pigment, trypethelonamide A and a novel dark violet red pigment 5'-hydroxytrypethelone along with three known dark violet-red pigments (-)trypethelone, (+)-trypethelone and (+)-8-hydroxy-7-methoxytrypethelone isolated from the mycobiont of lichen Trypethelium eluteriae (Basnet et al., 2019). Endolichenic fungi were isolated from the thallus of lichen and attracted the attention for their ability to yield a series of compounds comprising pigments. A modern study on the separation of active compounds from the endolichenic fungus Talaromyces funiculosus generated 3 molecules including ravenelin, which is a yellow colored homogeneous powder that also retain respectable antimicrobial action, thus making it valuable for food and pharmaceutical divisions (Padhi et al., 2019).

\subsection{Marine yeast}

Among the microorganisms, yeasts are conventionally used in food fermentation due to their less toxicity in nature compared to other microorganisms, in addition to their wide spread in almost all parts of the aquatic environment (Fell, 2001). Marine yeast form a respectable source of pigments, among which the most important recorded genera are Rhoaospojiaium, Candida, Metchnikowia, Cryptococcus, Kluyveromyces, Rhodotorula and Toruiopsjs (Hoog et al., 2001). Metabolites produced by marine yeast are more stable in different temperature and $\mathrm{pH}$. Morphologically, thirty different marine yeast species were isolated from twelve different samples collected from six different 
saltern areas of Kelambakkam, India and were named as AMBY130 and AMBY101. Among them, only three strains were able to produce pigments (Muthezhilan et al., 2014). Ghosh (2011) isolated yeast strains from West Bengal, India and were identified as Candida ipomoeae, Rhodototula mucilaginosa, Candida famata, Kodamaea anthophila, Debaryamyces hansensii, Candida succiphila and Pichia lachancei.

Methanol extract of the pigment produced by marine yeast Rhodotorula sp. (Amby109) exhibited antibacterial activity against different human pathogens, such as Enterococcus faecalis, Escherichia coli, Salmonella sp., Shigella sp., $V$. parahaemolyticus and Vibrio cholera (Muthezhilan et al., 2014). Additionally, different authors have studied the production of carotenoids by some yeast species such as Rhodotorula spp., which are broadly dispersed in nature and are capable of synthesizing specific types of carotenoids, such as torularhodin, $\beta$-carotene and torulene (Perrier $\boldsymbol{e t}$ al., 1995; Tinoi et al., 2005).

\subsection{Microalgae}

Microalgae comprise 16 classes and 72,500 species. The largest groups are Cyanobacteria (Cyanophyceae), golden algae (Chrysophyceae), diatoms (Bacillariophyceae) and green algae (Chlorophyceae); green algae and diatoms are the most commonly used for biotechnological applications (Guiry, 2012).

Microalgae represent tremendous bases of molecules that are beneficial for health, such as pigments, lipids, proteins, vitamins, polyunsaturated fatty acids, polysaccharides, and minerals awarding pronounced prospectives in different markets. The universal concern to discover microalgae-created products has been growing due to their highabundance, especially in the aquatic environment in addition to the value of their biological compounds (Christaki et al., 2015; Khanra et al., 2018).

Fig. (7) displays the evolution of publication number per year along the last ten years in the field of microalgal pigments. It is possible to detect an increase in the publication number in the periods from 2009 to 2013, 2014 to 2016, and from 2017 to 2019. While, in the periods from 2013-2014 and from 2016-2017, the number of publications was conserved. The results showed an $80 \%$ increase in the publication number concerning pigments from microalgae in the period from 2009 to 2019, which confirms the improved attentiveness in the area of pigments produced by microalgae. 


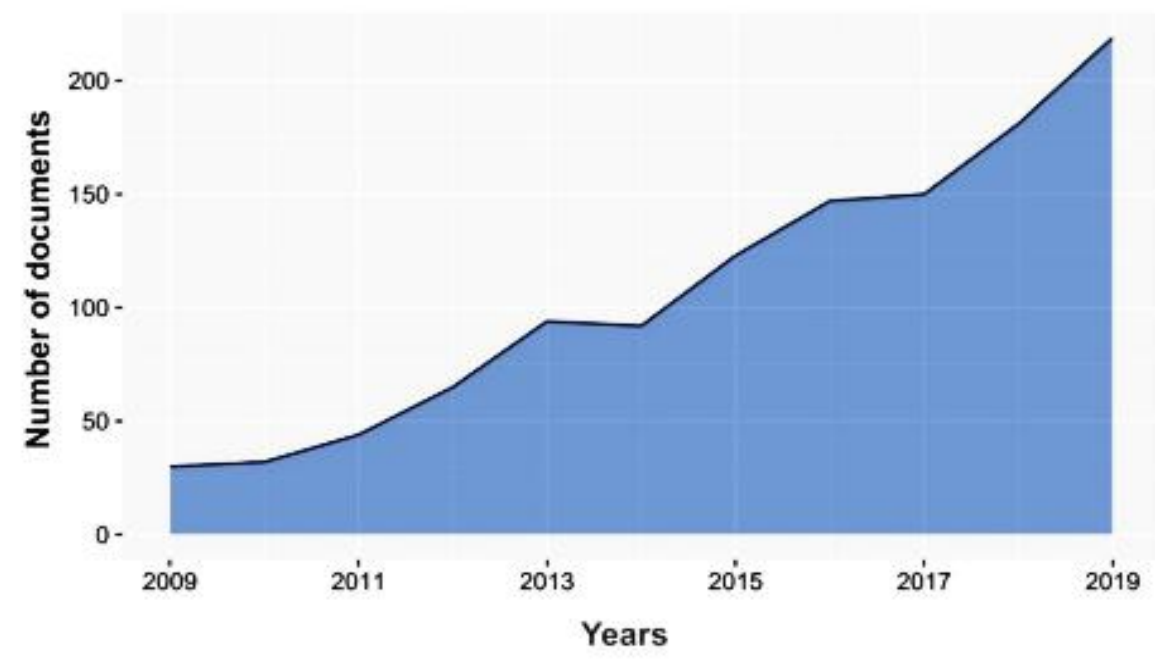

Fig. 7. The number of publications recorded from 2009 to 2019 in the area of

pigments produced by microalgae (Silva et al., 2020)

Among the varied range of compounds produced by microalgae, natural pigments are significant groups to be explored due to their health benefits (anti-inflammatory, anticancer and antioxidant) substituting artificial colorants (Rodrigues et al., 2015). Three groups of pigments exist in microalgae; namely, chlorophylls, phycobiliproteins and carotenoids (Christaki et al., 2015; D'Alessandro et al., 2016).

Chlorella sp. and Spirulina sp. are mostly used as food and feed additives due to their high lipid content, proteins, minerals and vitamins. They are the most abundant in the microalgae market used as pigment sources, such as carotenoids and phycobiliproteins. Haematococcus pluvialis and Dunaliella salina are used at industries to gain carotenoids, especially astaxanthin which exhibit antioxidant activity and $\beta$ carotene (vitamin A precursor), respectively (Da Silva Vaz et al., 2016).

For phycocyanin pigment produced by Spirulina according to a report published by the Future Market, the worldwide market was valued at USD 112.3 million in 2018. By the end of 2025, it is expected to exceed USD 232.9 million. The increasing awareness in phycocyanin pigment is noticeable through the recently approved European project SPIRALG (Horizon 2020) (www.spiralg.eu). Now a Givaudan business (the major flavor and fragrances producer) announced the production of phycocyanin through a new extraction line (Silva et al., 2020).

Phycocyanin synthesized by Spirulina has been used in the cosmetic/food industries, specifically in beverages (e.g., Bloo Tonic $®$, B-blue Spirulina drink, and M\&Ms® chocolates). Phycocyanin can also be used either as a colorant or food supplement due to its efficient benefits. In this context, AlgoSource 
(www.algosource.com), a French company, produces phycocyanin as a liquid extract (Spirulysat $\left.{ }^{\circledR}\right)$ that is sold in phials $(10 \mathrm{~mL})$. Another company under the name of Spira (www.spirain.com) yields phycocyanin in the form of powder (Electric Sky®) to be used for health benefits (food supplement) and coloring applications (Silva et al., 2020).

\section{Applications of biopigments in the marine environment}

\subsection{Application in aquaculture}

Aquaculture is developed in the coastal area of the world. Now, $~ 50 \%$ of the fish production in the world for human feeding and the non-fish production are based on aquaculture (FAO, 2016). Egypt, India, China, Bangladesh, and Vietnam are the main fish manufacturers. It is important to regulate the cycle of fish reproduction and manage the capability of feeding them during part/ whole of the breeding cycle. The value of the diet is critical, owing to its effect on the organoleptic value and the time of breeding. Thus, studies focused on the increase of growth and health of farmed species. As a result of the deficiency of diversity of food under breeding conditions, addition of pigments to the diets is particularly significant. In this respect, canthaxanthin and asthaxanthin are used in feeding salmonid (Serive \& Bach, 2018), making the final product more simply marketed.

In the Western countries, consumers are ready to pay more and find their demanded food in return. In this percepective, the use of asthaxanthin to color prawns reared in aquaculture was reported. In aquaculture, the high density of rearing of larval stage causes great rate of mortality and oxidative stress. To overcome this, farmers rear in green waters to improve larval survival. The effect is not completely understood, but the composition of pigment might have a role. Larvae have phototaxis, which is critical for their survival, and this can be improved using carotenoid supplements such as astaxanthin. Zeaxanthin and Lutein might have an essential role in this physiological function. Astaxanthin supplements can promote the number of eggs during laying with respect to the stripped jack fish (Pseudocaranx dentex). $\beta$-Carotene can be used in diet of prawn before harvesting (175 ppm during 5-6 weeks for Penaeus monodon). The action of carotenoids is not restricted to pigmentation, but it can improve growth, tolerance to salinity and ammonia as well. Phycobiliprpteins and chlorophylls can be implemented on diets when living prey is used as a feed of cultivated species ( Boonyaratpalin $\boldsymbol{e t}$ al., 2001).

\subsection{Antifouling agents}

Billions of dollars are spent every year for antifouling agents to control activities of fouling on diverse matters existing in the marine environment. Biofouling on ships can promote frictional resistance causing a rise in fuel consumption and other resultant environmental problems. Heavy metal-based antifouling agents cause severe environmental complications, which further obligate the requisite for "eco-friendly" 
antifoulants. Scientists have also displayed the use of pigments- based antifouling agents, for example, prodigiosin gained from Serratia. sp. showed antifouling activity towards marine Gallionella sp. and Alteromonas sp. that are known as fouling bacterial species. It also repressed the adhesion of Cyanobacterium sp. on the glass surface (Priya et al., 2013). Similarly, the pigment polymelanin made by the marine bacterium $P$. lipolytica sp. inhibited metamorphosis and reduced the settlement of invertebrate larvae (Zheng $\boldsymbol{e t}$ al., 2017), thereafter demonstrating the action of marine pigments as prospective antifoulants.

\subsection{Absorption of heavy metals}

The extracted melanin from bacteria has also been described for the treatment of heavy metals. Manirethan et al. (2018, 2020) used the extracted melanin pigment from $P$. stutzeri for heavy metals absorption of lead, copper, mercury, arsenic and chromium, where the absorption may be due to the presence of the $\mathrm{COOH}$, phenolic $\mathrm{OH}$ and $\mathrm{NH}$ groups, and the maximum efficiency was absorbed in mildly acidic to neutral range of $\mathrm{pH}$. The efficiency of melanin in removing the arsenic by chemisorption was proved, and melanin displayed a thermostability up to $120^{\circ} \mathrm{C}$ and reached a peak of absorption of arsenic at $\mathrm{pH}$ 4-6. Impregnated melanin was oxidized to arsenate and finally removed the $\mathrm{Cu}$ and $\mathrm{Fe}$ by using $\mathrm{HCl}$ for the recycling process of melanin. Then, it was re- soaked with fresh $\mathrm{Fe}$ and $\mathrm{Cu}$ elements for absorption. This revealed $99 \%$ efficiency to 4 absorption and desorption cycles.

Batch adsorption studies showed that $280 \mathrm{mg} / \mathrm{g}$ of lead and $169 \mathrm{mg} / \mathrm{g}$ of copper were adsorbed by immobilized melanin-alginate beads. The metal ion adsorption capacity of the melanin-alginate beads was relatively significant compared to alginate beads (Sajjan et al., 2013).

\section{Pathogenicity of pigments producing microbes}

In spite of the various acknowledged applications of pigments, the studies suggest that some bacterial producers of pigments are evolved in humans and in aquaculture farms as pathogens. Chromobacterium violaceum producing Violacein cause infections in adults and children (Jitmuang, 2008). Serratia marcescens produces Prodigiosin, which infects invertebrates, vertebrate, humans and insects (Grimont \& Grimont, 2006; Petersen \& Tisa, 2013). Strains of $C$. violaceum and $S$. marcescens are opportunistic pathogenic bacteria to humans (Mahlen, 2011; Sharmin \& Kamal, 2019). Nonetheless, no reports are detected about the contribution of prodigiosin and violacein in virulence function. Notably, prodigiosin pigment did not cause a virulence role in entomopathogenic $S$. marcescens (Zhou et al., 2016). Yet, few pigments such as bacterial melanins (Nosanchuk \& Casadevall, 2003) and pyoverdines (Kang et al., 2019) regulated virulence function.

Fungi such as Monascus and Fusarium produce red pigment known as mycotoxins linked to pathogenicity (Wang et al., 2005). Thus, investigators are searching for species of fungi that do not yield toxins, and it was suggested that determining the 
pathogenicity (hemolytic activity) of the produced pigment would aid avoiding toxicities and mortality (Mapari et al., 2009).

\section{Future perspective}

Some limitations such as lower stability, high cost needed for large scale production, variations in operational parameters, less percentage regarding annual production, specifications concerning microorganisms capable of producing different colors, and technological limitations cause delay in the advancement of the industrial production and the extraction of pigments in a pure form. Future researches should be carried out particularly to find the easiest way for gathering microbial pigments to enhance their applications in industry. Correspondingly, there is a requirement to regard several operational factors that may lead to a disparity due to the alteration and progress of new process by using low cost agrowaste as substrate in the future to recognize high production of pigments. Research on numerous technologies that could decrease the cost and increase the yields of pigment production on large scale should be conducted in the future.

Extending the survey on the undiscovered samples from novel environments belonging to marine ecosystem would surely provide talented results in finding new metabolites from promising microbes. Numerous pigment producing microbes have been stated till now, while their bioactivities aught to be assessed. Therefore, creating records from novel microorganisms is of great significance in understanding the biological actions of pigments. The survey of pigment chemodiversity is still prevalent in biotechnologies, agronomy, aquaculture and oceanography. Pigments may receive a renewal awareness for the discovery of drugs and other promising applications in the coming decades.

\section{Conclusion}

Nature is a gorgeous source of pigmented microbes, such as bacteria, actinobacteria, fungi and yeasts. Natural pigmented compounds became more demandable and valuable over synthetic pigments. Marine ecosystem has been a focused poin for the investigation of novel natural pigmented compounds with an extensive array of bioactivities owing to massive marine resources, which comprise numerous novel pigment producing microbes. Remarkably, microbial pigments represent attractive field of study in life sciences due to the innumerable applications in different activities.

\section{REFERENCES}

Agogué, H.; Casamayor, E.O.; Bourrain, M.; Obernosterer, I.; Joux, F.; Herndl,

G.J. and Lebaron, P. (2005). A survey on bacteria inhabiting the sea surface microlayer of coastal ecosystems. FEMS Microbiology Ecology, 54(2): 269-280 
Ali, I.; Siwarungson, N.; Punnapayak, H.; Lotrakul, P.; Prasongsuk, S. and Bankeeree, W., et al. (2014). Screening of potential biotechnological applications from obligate halophilic fungi, isolated from a man-made solar saltern located in Phetchaburi province, Thailand. Pak. J. Bot., 46: 983-988.

Almeida, A.; Dethoup, P.; Singburaudom, N.; Lima, R.; Vasconcelos, M.H.; Pinto, M. and Kijjoa, A. (2010). The in vitro anticancer activity of the crude extract of the spongeassociated fungus Eurotium cristatum and its secondary metabolites. J. Nat. Pharm., $1: 25-29$.

Asker, D. (2017). Isolation and characterization of a novel, highly selective astaxanthinproducing marine bacterium. J. Agric. Food. Chem., 65: 9101-9109.

Basnet, B.B.; Liu, L.; Zhao, W.; Liu, R.; Ma, K. and Bao, L. (2019). New 1, 2naphthoquinone-derived pigments from the mycobiont of lichen Trypethelium eluteriae Sprengel. Nat. Prod. Res., 33: 2044-2050.

Bech, P.K.; Lysdal, K.L.; Gram, L.; Bentzon-Tilia, M. and Strube, M.L. (2020) Marine sediments hold an untapped potential for novel taxonomic and bioactive bacterial diversity. mSystems, 5: e00782-20.

Berradi, M.; Hsissou, R.; Khudhair, M.; Assouag, M.; Cherkaoui, O.; El Bachiri, A. and El Harfi, A. (2019). Textile finishing dyes and their impact on aquatic environs. Heliyon, 5: e02711.

Blockley, A. and Elliott, D.R. (2017). Symbiotic microbes from marine invertebrates: Driving a new era of natural product drug discovery. Diversity, 9: ID 49.

Boonyaratpalin, M.; Thongrod, S. and Supamattaya, K. et al. (2001). Effects of $\beta$ carotene source, Dunaliella salina, and astaxanthin on pigmentation, growth, survival and health of Penaeus monodon. Aquacult. Res., 32 (s1): 182-190.

Brotosudarmo, T.H.P.; Limantara, L.; Setiyono, E. and Heriyanto. (2020) Structures of astaxanthin and their consequences for therapeutic application. Int J Food Sci., 1417.

Calcott, M. J.; Ackerley, D. F.; Knight, A.; Keyzers, R. A. and Owen, J. G. (2018). Secondary metabolism in the lichen symbiosis. Chem. Soc. Rev., 47: 1730-1760.

Caro, Y.; Venkatachalam, M.; Lebeau, J.; Fouillaud, M. and Dufossé, L. (2017). "Pigments and colorants from filamentous fungi," in Fungal Metabolites, eds J.- M. Mérillon and K. G. Ramawat (Springer International Publishing), 499-568.

Chakraborty, I.; Redkar, P.; Munjal, M.; Kumar, S.R. and Rao, K. V. (2015). Isolation and characterization of pigment producing marine actinobacteria from mangrove soil and applications of bio-pigments Der Pharmacia Lettre, 7 (4):93-100.

Chatragadda, R. and Dufossé, L. (2021). Ecological and biotechnological aspects of pigmented microbes: AWay forward in development of food and pharmaceutical grade pigments. Microorganisms, 9: 637.

Christaki, E.; Bonos, E. and Florou-Paneri, P. (2015) Innovative Microalgae Pigments as Functional Ingredients in Nutrition. In Handbook of Marine Microalgae: 
Biotechnology Advances; Kim, S.-K., Ed.; Academic Press: Cambridge, MA, USA, 2015; pp. 233-243, ISBN 9780128011249.

Chuyen, H. V. and Eun, J. B. (2017). Marine carotenoids: Bioactivities and potential benefits to human health. Crit. Rev. Food Sci., 57: 2600-2610. doi: 10.1080/10408398.2015.1063477.

Coker, J. A. (2016). Extremophiles and biotechnology: current uses and prospects. F1000Res. 5: 396.

Connon, S.A. and Giovannoni, S.J. (2002). High-throughput methods for culturing microorganisms in very-lownutrient media yield diverse new marine isolates. Appl. Environ. Microbiol., 68: 3878-3885.

D'Alessandro, E.B. and Antoniosi Filho, N.R. (2016). Concepts and studies on lipid and pigments of microalgae: A review. Renew. Sustain. Energy Rev., 58: 832-841.

Da Silva Vaz, B.; Moreira, J.B.; de Morais, M.G. and Costa, J.A.V. (2016). Microalgae as a new source of bioactive compounds in food supplements. Curr. Opin. Food Sci., 7: 73-77.

DeBritto, S.; Gajbar, T.D.; Satapute, P; Sundaram, L.; Lakshmikantha, R.Y.; Jogaiah, S. and Ito, S. (2020). Isolation and characterization of nutrient dependent pyocyanin from Pseudomonas aeruginosa and its dye and agrochemical properties. Sci Rep., 10: ID 1542.

DePriest, P. T. (2004). Early molecular investigations of lichenforming symbionts: 1986-2001. Annu. Rev. Microbiol., 58: 273-301.

Duarte, A. W. F.; De Menezes, G. C. A. E.; Silva, T. R.; Bicas, J. L.; Oliveira, V. M. and Rosa, L. H. (2019). "Antarctic fungi as producers of pigments," in Fungi of Antarctica, ed. L. Rosa (Springer: Cham), 305-318.

Duffose, L. (2006). Microbial production of food grade pigments, food grade pigments. Food Technol Biotechnol 44(3):313-321.

Dufossé, L. (2020). Research, Development, and Production of Microalgal and Microbial Biocolorants. In Bioprocessing for Biomolecules Production; Molina, G., Gupta, V.K., Singh, B.N., Gathergood, N., Eds.; John Wiley \& Sons Ltd.: Chichester, UK.

Dufosse, L.; Fouillaud, M.; Caro, Y.; Mapari, S. A. and Sutthiwong, N. (2014). Filamentous fungi are large-scale producers of pigments and colorants for the food industry. Curr. Opin. Biotech., 26: 56-61.

FAO. (2016) .The State of World Fisheries and Aquaculture 2016. Contributing to Food Security and Nutrition for All. Rome. 200 pp.

Fell, J.W. (2001). Collection and identification of marine yeasts. In Methods in Microbiology, PaulJ (ed.). Academic Press: New York; 347-356.

Flórez, L.V.; Biedermann, PHW.; Engl, T. and Kaltenpoth, M. (2015) Defensive symbioses of animals with prokaryotic and eukaryotic microorganisms. Nat Prod. Rep., 32: 879-1156. 
Fouillaud, M.; Venkatachalam, M.; Llorente, M.; Magalon, H.; Cuet, P. and Dufossé, L. (2017). Biodiversity of pigmented fungi isolated from marine environment in La Réunion island, Indian ocean: new resources for colored metabolites. J. Fungi, 3:36.

Galasso, C.; Corinaldesi, C. and Sansone, C. (2017). Carotenoids from marine organisms: Biological functions and industrial applications. Antioxidants, 6: ID 96.

Ghosh, S.K. (2011). Study of yeast flora from Fruit of Syzyzium cumini. Agri. Bio.J N.America, 2(8):1166- 1170.

Gmoser, R.; Ferreira, J. A.; Lennartsson, P. R. and Taherzadeh, M. J. (2017). Filamentous ascomycetes fungi as a source of natural pigments. Fungal Biol. Biotechnol., 4:4.

Grimont, F. and Grimont, P.A.D. (2006).The genus Serratia. In The Prokaryotes; Dworkin, M., Falkow, S., Rosenberg, E., Schleifer, K.H., Stackebrandt, E., Eds.; Springer: New York, NY, USA, 2006; pp. 219-244.

Guiry, M.D. (2012). HOW MANY SPECIES OF ALGAE ARE THERE?, J. Phycol. 48: 1057-1063.

Hathaway, J.J.M.; Garcia, M.G.; Balasch, M.M.; Spilde, M.N.; Stone, F.D.; Dapkevicius, M.D.L.N.; Amorim, I.R.; Gabriel, R.; Borges, P.A. and Northup, D.E. (2014). Comparison of bacterial diversity in Azorean and Hawaiian lavacave microbial mats. Geomicrobiol. J., 31: 205-220.

Hermansson, M.; Jones, G.W. and Kjelleberg, S. (1987). Frequency of antibiotic and heavy metal resis-tance, pigmentation, and plasmids in bacteria of the marine airwater interface. Appl. Environ. Microbiol., 1: 2338-2342.

Hoog, G.S.; Guarro, J.; Gene, J.; Figueras, M. J. Atlas of Clinical Fungi. 2nd edition. Washington: ASM Pressp. 2001. Guiry, M.D. How many species of algae are there? J. Phycol. 2012, 1063, 1057-1063.

Jamee, R. and Siddique, R. (2019). Biodegradation of synthetic dyes of textile effluent by microorganisms: An environmentally and economically sustainable approach. Eur. J. Microbiol. Immunol., 9: 114-118. Microorganisms, 9: 114-118.

Jiao, H., Jiang, D., Hu, X., Du, W., Ji, L., Yang, Y., et al. (2021). Mitocytosis, a migrasome-mediated mitochondrial quality-control process. Cell. 184(11) 2896-2910.

Jitmuang, A. (2008). Human Chromobacterium violaceum infection in Southeast Asia: Case reports and literature review. Southeast Asian J. Trop. Med. Public Health. 39: 452-460.

Joint, I., Mühling, M. and Querellou J. (2010). Culturing marine bacteria: An essential prerequisite for biodiscovery: Minireview. Microb. Biotechnol., 3: 564-575.

Joshi, V.; Attri, D.; Bala, A. and Bhushan S. (2003). Microbial Pigments. Indian J Biotechnol 2:362-369.

Joye, S. and Kostka, J.E (2020). Microbial Genomics of the Global Ocean System. American Academy of Microbiology, Washington DC. 
Kalra1, R.; Conlan, X.A. and Goel, M. (2020). Fungi as a potential source of pigments: Harnessing filamentous fungi. Fronti. Chemi., 8 | Article 369

Kang, D.; Revtovich, A.V.; Chen, Q.; Shah, K.N.; Cannon, C.L. and Kirienko, N.V. (2019). Pyoverdine-dependent virulence of Pseudomonas aeruginosa isolates from cystic fibrosis patients. Front. Microbiol., 10: 2048.

Kathiresan, K. and Bingham, B. L. (2001). Biology of mangroves and mangrove ecosystems. Adv. Mar. Biol., 40: 84-254.

Khanafari, A.; Khavarinejad, D.; Mashinchian, A. (2009). Solar salt lake as natural environmental source for extraction halophilic pigments. Iran. J. Microbiol, 2, 103109.

Khanra, S.; Mondal, M.; Halder, G.; Tiwari, O.N.; Gayen, K.and Bhowmick, T.K. (2018). Downstream processing of microalgae for pigments, protein and carbohydrate in industrial application: A review. Food Bioprod. Process.110: 60-84.

Kim, M.C.; Cullum, R.; Hebishy, AMS.; Mohamed, H.A.; Faraag, A.H.I.; Salah, N.M.; Abdelfattah, M.S. and Fenical, W (2020). Mersaquinone, a new tetracene derivative from the marine-derived Streptomyces sp. EG1 exhibiting activity against methicillin-resistant Staphylococcus aureus (MRSA). Antibiotics, 9: ID 252.

Kogej, T.; Wheeler, M. H.; Lanišnik RiŽner, T. and Gunde-Cimerman, N. (2004). Evidence for 1, 8-dihydroxynaphthalene melanin in three halophilic black yeasts grown under saline and non-saline conditions. FEMSMicrobiol.Lett., 232: 203-209.

Lellis, B.; Fávaro-Polonio, C.Z.; Pamphile, J.A. and Polonio, J.C. (2019). Effects of textile dyes on health and the environment and bioremediation potential of living organisms. Biotechnol. Res. Innov., 3: 275-290.

Liang, Y.; Xie, X.; Chen, L.; Yan, S.; Ye, X.; Anjum, K.; Huang, H. and Lian, X., et al (2016) Bioactive polycyclic quinonesnfrom marine Streptomyces sp. 182SMLY. Mar Drugs, 14: ID 10.

Liu, H.; Zhang, C.; Zhang, X.; Tan, K.; Zhang, H.; Cheng, D.; Ye, T. and Li S, et al (2020). A novel carotenoids-producing marine bacterium from noble scallop Chlamys nobilis and antioxidant activities of its carotenoid compositions. Food Chem., 320: ID 126629.

Mahlen, S.D. (2011). Serratia infections: From military experiments to current practice. Clin. Microbiol. Rev., 24: 755-791.

Manirethan, V.; Raval, K. and Balakrishnan, R. M. (2020). Adsorptive removal of trivalent and pentavalent arsenic from aqueous solutions using iron and copper impregnated melanin extracted from the marine bacterium Pseudomonas stutzeri. Environ. Pollut., 257: 113576.

Manirethan, V.; Raval, K.; Rajan, R.; Thaira, H. and Balakrishnan, R. M. (2018). Data on the removal of heavy metals from aqueous solution by adsorption using melanin nanopigment obtained from marine source: Pseudomonas stutzeri. Data brief. 20: $178-189$. 
Mapari, S.A.S.; Meyer, A.S.; Thrane, U. and Frisvad, J.C. (2009). Identification of potentially safe promising fungal cell factories for the production of polyketide natural food colorants using chemotaxonomic rationale. Microb. Cell Fact., 8: 24.

Miteva, V.I.; Sheridan, P.P.and Brenchley, J.E. (2004). Phylogenetic and physiological diversity of micro-organisms isolated from a deep greenland glacier ice core. Appl. Environ. Microbiol., 70: 202-213.

Miyagawa, H.; Hamada, N.; Sato, M. and Ueno, T. (1994). Pigments from the cultured lichen mycobionts of Graphis scripta and G. Desquamescens, Phytochemistry. 36(5):1319-22

Muthezhilan, R.; Ragul, R.; Pushpam, A.C.; R Narayanan, R.L. and Hussain, A.J. (2014). Isolation, optimization and extraction of microbial pigments from marine yeast Rhodotorula Sp (Amby109) as food colourants. BioSci. Biotechnol. Res., 11(1): 271-278.

Nawaz, A.; Chaudhary, R.; Shah, Z.; Dufossé, L.; Fouillaud, M.; Mukhtar, H. and ul Haq, I. (2021). An overview on industrial and medical applications of biopigments synthesized by marine bacteria. Microorganisms, 9: 11.

Nguyen, K. H.; Chollet-Krugler, M.; Gouault, N. and Tomasi, S. (2013). UV protectant metabolites from lichens and their symbiotic partners. Nat. Prod. Rep. 30, 1490-1508. doi: 10.1039/c3np70064j

Nosanchuk, J.D. and Casadevall, A. (2003). The contribution of melanin to microbial pathogenesis. Cell. Microbiol., 5: 203-223.

Okafor, S.N.; Obonga, W.; Ezeokonkwo, M.A.; Nurudeen, J.; Orovwigho, U. and Ahiabuike, J. (2016). Assessment of the health implications of synthetic and natural food colourants-A Critical Review. UK J. Pharm. Biosci., 4: 1-11.

Padhi, S.; Masi, M.; Cimmino, A.; Tuzi, A.; Jena, S. and Tayung, K., et al. (2019). Funiculosone, a substituted dihydroxanthene-1,9-dione with two of its analogues produced by an endolichenic fungus Talaromyce funiculosus and their antimicrobial activity. Phytochem, 157:175-183.

Parmar, R. and Singh, C. (2018). A comprehensive study of eco-friendly natural pigment and its applications. Biochem. Biophys. Rep., 13: 22-26.

Perrier V, Dubreucq E, Galzy P. (1995). Fatty acid and carotenoid composition of Rhodotorula strains. Arch Microbiol 1995, 164:173-179.

Petersen, L.M. and Tisa, L.S. (2013). Friend or foe? a review of the mechanisms that drive Serratia towards diverse lifestyles. Can. J. Microbiol., 59: 627-640.

Pombeiro-Sponchiado, S. R.; Sousa, G. S.; Andrade, J. C.; Lisboa, H. F. and Gonçalves, R. C. (2017). "Production of melanin pigment by fungi and its biotechnological applications," in Melanin, ed M. Blumenberg (London, UK: InTech): 47-74. 
Priya, M.; Kumarasamy, T.; Nick, P.; Mark, L.; Po-Ru, L.; Periyasamy, G.;Bonnie B.; David R. and Lalji S. (2013). Genetic Evidence for Recent Population Mixture in India. Am J Hum Genet 5; 93(3): 422-438.

Rajapaksha, G.K.M.; Wansapala, M.A.J. and Silva, A.B.G. (2017). Detection of Synthetic Colours in Selected Foods \& Beverages Available in Colombo District, Sri Lanka. Int. J. Sci. Res., 6: 801-808.

Ramesh, C.; Vinithkumar, N.V.; Kirubagaran, R.; Venil, C.K. and Dufossé, L. (2019). Multifaceted applications of microbial pigments: Current knowledge, challenges and future directions for public health implications. Microorganisms, 7: 186.

Ramesh, C.; Vinithkumar, N.V.; Kirubagaran, R.; Venil, C.K. and Dufoseé, L. (2020). Applications of prodigiosin extracted from marine red pigmented bacteria Zooshikella sp. and Actinomycete Streptomyces sp. Microorganisms, 8: ID 556.

Rani, M. H. S.; Ramesh, T.; Subramanian, J. and Kalaiselvam, M. (2013). Production and characterization of melanin pigment from halophilic black yeast Hortaea werneckii. Int. J. Pharm. Res. Rev. 2: 9-17.

Rao, N.; Prabhu, M.; Xiao, M. and Li, W. J. (2017). Fungal and bacterial pigments: secondary metabolites with wide applications. Front. Microbiol., 8:1113.

Rodrigues, D.B.; Menezes, C.R.; Mercadante, A.Z.; Jacob-Lopes, E. and Zepka, L.Q. (2015). Bioactive pigments from microalgae Phormidium autumnale. Food Res. Int., 77: 273-279.

Roy, A.K.C. (2018). Eco-friendly dyes and dyeing. Adv. Mat. Technol. Environ. 2: 145176.

Saini, R.D. (2017). Textile organic dyes: Polluting effects and elimination methods from textile waste water. Int. J. Chem. Eng. Res., 9: 121-136.

Sajjan, Shrishailnath, S.; Anjaneya, O.; Guruprasad, B.; Kulkarni, Anand S. Nayak, Suresh B. Mashetty, and Karegoudar, T. B. (2013). Properties and functions of melanin pigment from Klebsiella sp. GSK Korean J. Microbiol. Biotechnol., 41(1): 60-69.

Sen, T., Barrow, C. J., and Deshmukh, S. K. (2019). Microbial pigments in the food industry - challenges and the way forward. Front. Nutr., 6: 7.

Serive, B. and Bach, S. (2018). Marine pigment diversity: Applications and potential. Blue Biotechnol., Production and Use of Marine Molecules, Volume 1

Setiyono, E.; Adhiwibaw, M.A.S.; Indrawati, R., Prihastyanti, M.U.U., Shioi, Y. and Brotosudarmo, T.H.P. (2020) An Indonesian marine bacterium, Pseudoalteromonas rubra, produces antimicrobial prodiginine pigments. ACS Omega, 5: 4626-4635.

Sharmin, S.; Kamal, S.M. (2019). Review on Chromobacterium violaceum, a rare but fatal bacteria needs special clinical attention. AnwerKhan Mod. Med. Coll. J. 10: 169175. 
Sigwart, J.D.; Blasiak, R.; Jaspars M.; Jouffray J-B. and Tasdemir, D (2021). Unlocking the potential of marine biodiscovery. Nat. Prod. Rep.,

Silva, S.C.; Ferreira, I.C.; Dias, M.M. and Barreiro, M. (2020). Microalgae-derived pigments: A 10-Year Bibliometric Review and industry and market trend analysis. Molecules, 25: 3406.

Staley, J.T. and Konopka, A. (1985). Microorganisms in aquatic and terrestrial habitats. Annu. Rev. Microbiol., 39: 321-346.

Sun, J.; Zhang, K.; Wan, H.; Ma, P.; Tang, Q. and Zhang, S. (2019). Impact of Nudging Strategy on the Climate Representativeness and Hindcast Skill of Constrained EAMv1 Simulations, JAMES., 11(12): 3911-3933.

Tawfike, A.; Attia, E.Z.; Desoukey, S.Y.; Hajjar, D.; Makki, A.A.; Schupp, P.J.; Edrada-Ebel, R.A. and Abdelmohsen, U.R. (2019). New bioactive metabolites from the elicited marine sponge-derived bacterium Actinokineospora spheciospongiae sp. nov. AMB Express, 9: ID 12.

Tinoi, J.; Rakariyatham, N. and Deming, R.L. (2005). Simplex optimization of carotenoid production by Rhodotorula glutinis using hydrolyzed mung bean waste flour as substrate. Process Biochem., 40: 2551-2557.

Torregrosa-crespo, J.; Montero, Z.; Fuentes, J.L.; Reig, M., Carlos, V. and Martinez-Espinosa, R.M. (2018) Exploring the valuable carotenoids for the largescale production by marine microorganisms. Mar Drugs, 16: ID 203.

Velmurugan, P.; Venil, C.K.; Ravi, A.V. and Dufossé, L. (2020). Marine bacteria is the cell factory to produce bioactive pigments: A Prospective pigment source in the Ocean. Front. Sustain. Food Systems., 4: 1-7.

Venil, C.K. and Lakshmanaperumalsamy, P. (2009). An insightful overview on microbial pigment, prodigiosin. Elect. J. Biol., 5(3): 49-61.

Venil, C.K.; Dufossé, L. and Devi, P.R. (2020). Bacterial Pigments: Sustainable Compounds With Market Potential for Pharma and Food Industry. Front. Sustain. Food Syst., 4: 100.

Venkatachalam, M.; Gérard, L.; Milhau, C.; Vinale, F.; Dufossé, L and Fouillaud, M. (2019). Salinity and temperature influence growth and pigment production in the marine-derived fungal strain Talaromyces albobiverticillius 30548. Microorganisms, $7: 10$.

Wang, Y.Z.; Ju, X.L. and Zhou, Y.G. (2005). The variability of citrinin production in Monascus type cultures. Food Microbiol., 22: 145-148.

Wang,W. L.; Lu, Z. Y.; Tao, H. W.; Zhu, T. J.; Fang, Y. C.; Gu, Q. Q. and et al. (2007). Isoechinulin-type alkaloids, variecolorins A-L, from halotolerant Aspergillus variecolor. J. Nat. Prod., 70: 1558-1564.

Xie, F.; Chang, W.; Zhang, M.; Li, Y.; Li, W. and Shi, H., et al. (2016). Quinone derivatives isolated from the endolichenic fungus Phialocephala fortinii are Mdr1 
modulators that combat azole resistance in Candida albicans. Sci. Rep. 6:33687. doi: 10.1038/srep33687

Xu, J.; Nakazawa, T.; Ukai, K.; Kobayashi, H.; Mangindaan, R.E. and Wewengkang, D.S., et al. (2008). Tetrahydrobostrycin and 1deoxytetrahydrobostrycin, two new hexahydroanthrone derivatives, from a marinederived fungus Aspergillus sp. J. Antibiot. Res., 61: 415-419.

Yurkov, V.V.; Krieger, S.; Stackebrandt, E. and Beatty, J.T. (1999). Citromicrobium bathyomarinum, a novel aerobic bacterium isolated from deep-sea hydrothermal vent plume waters that contains photosynthetic pigment-protein complexes. J. Bacteriol., 181: 4517-4525.

Zhang, L.;Tian, X.; Kuang, S.; Liu, G.; Zhang, C. and Sun, C (2017). Antagonistic activity and mode of action of phenazine-1-carboxylic acid, produced by marine bacterium Pseudomonas aeruginosa PA31x, against Vibrio anguillarum in vitro and in a zebrafish in vivo model. Front Microbiol., 8: ID 289.

Zhang, X.; Wei, W. and Tan R (2015). Symbionts, a promising source of bioactive natural products. Sci China Chem., 58: 1097-1109.

Zhang, X.F.; Yao, T.D.; Tian, L.D.; Xu, S.J. and An, L.Z. (2008). Phylogenetic and physiological diversity of bacteria isolated from puruogangri ice core. Microb. Ecol., 55: 476-488.

Zheng, C.J.; Shao, C. L.; Guo, Z.Y.; Chen, J.F.; Deng, D.S. and Yang, K. L., et al. (2012). Bioactive hydroanthraquinones and anthraquinone dimers from a soft coralderived Alternaria sp. fungus. J. Nat. Prod., 75: 189-197.

Zhou,W.; Li, J.H.; Chen, J.; Liu, X.Y.; Xiang, T.T.; Zhang, L. and Wan, Y.J. (2016).The red pigment prodigiosin is not an essential virulence factor in entomopathogenic Serratia marcescens. J. Invertebr. Pathol., 136: 92-94. 